\title{
Penilaian dalam Konseling Kelompok Gestalt
}

\author{
Indah Sukmawati ${ }^{1}$, Neviyarni Neviyarni ${ }^{2}$, Yeni Karneli ${ }^{3}$, Netrawati Netrawati ${ }^{4}$ \\ ${ }^{1234}$ Universitas Negeri Padang
}

\begin{abstract}
In gestalt group counseling, group members can make use of their presence in the group to channel and express their thoughts, feelings, and behavior so far that is problematic. To be able to achieve effective and efficient group activities, a gestalt group leader must be able to carry out activities according to the stages of forming group counseling. Furthermore, the gestalt group leader must understand the problems of group membership, conflicts that arise in group counseling, self-disclosure among members, and close / stop group activities. This needs an assessment so that what is done goes according to the purpose of group counseling. Counselors should ideally carry out assessments throughout the range of activities, starting from the beginning of counseling to the end of counseling, where the counselor will obtain data that can be utilized to compile, organize and evaluate group counseling activities that are carried out in accordance with the client's conditions described through assessment activities.
\end{abstract}

Keyword: Penilaian Konseling, Kelompok Gestalt.

This is an open access article distributed under the Creative Commons Attribution License, which permits unrestricted use,
distribution, and reproduction in any medium, provided the original work is properly cited. C2019 by author

\section{PENDAHULUAN}

Prosedur penilaian hendaknya digunakan selama proses konseling, dan konselor yang terampil tahu bagaimana dan kapan mengumpulkan informasi penilaian lebih lanjut atau menggunakan informasi yang dikumpulkan sebelumnya. Mariush (Whiston, 2009) berpendapat bahwa banyak praktisi menganggap penilaian sebagai kegiatan yang hanya terjadi pada sesi awal. Idealnya konselor tidak hanya menggunakan penilaian untuk membuat diagnosis dan berhenti sampai di situ, seharusnya menggunakan teknik penilaian sampai memantau efek konseling adalah cara yang seharusnya dilakukan agar pelayanan konseling yang dilaksanakan sesuai dengan harapan sasaran sebagaimana mestinya.

Layanan konseling kelompok merupakan salah satu jenis layanan yang dapat dilaksanakan konselor dengan menggunakan berbagai pendekatan konseling, salah satunya pendekatan gestalt. Area yang paling penting diperhatikan dalam konseling gestalt adalah pemikiran dan perasaan yang dialami individu pada saat sekarang. Kecenderungan dasar setiap individu adalah mengupayakan keseimbangan, namun dalam berinteraksi dengan lingkungan banyak indvidu bertemu ketidakseimbangan yang mengganggu, baik melalui faktor eksternal (tuntutan dan lingkungan) maupun internal (kebutuhan), apabila tidak terpenuhi kebutuhan maka akan berada pada keadaan sakit (Jones, 2011).

Peluang individu untuk bertahan hidup secara fisik hampir tidak ada jika diserahkan sepenuhnya kepada dirinya sendiri. Manusia membutuhkan orang lain untuk bertahan hidup secara fisik. Peluang hidup psikologis dan emosionalnya bahkan lebih rendah jika dia dibiarkan sendirian. Pada tingkat psikologis, manusia membutuhkan kontak dengan manusia lain. Perasaan manusia akan keterkaitannya dengan kelompok itu sama alaminya dengan perasaan keterikatannya dengan salah satu dari kelangsungan hidup fisiologisnya (Perls, 1981). Oleh sebab itu terapi gestalt dapat dilakukan dalam format kelompok untuk membantu klien-klien yang bermasalah dalam kondisi emosional dan komunikasi interpersonal.

Oleh sebab itu, persiapan dalam kegiatan konseling kelompok sangat diperlukan demi tercapainya penyelenggaraan konseling kelompok yang berhasil, karena kematangan, kesiapan, dan susunan keanggotaan 
kelompok memiliki peranan yang menentukan dalam kesuksesan atau kegagalan sebuah konseling kelompok (Gladding, 2012). Konseling kelompok sering kali berorientasi pada masalah, dan sebagian besar anggota menentukan isi dan tujuan mereka. Anggota kelompok biasanya tidak memerlukan rekonstruksi kepribadian yang ekstensif, dan kekhawatiran mereka umumnya berkaitan dengan tugas perkembangan dalam rentang kehidupan (Corey, 2016).

\section{Tahap-tahap Pembentukan Konseling Kelompok}

Menggunakan pendekatan Gestalt membutuhkan pengetahuan menyeluruh dari masing-masing teknik dan keterampilan untuk menerapkannya. Penekanan teori pada kesadaran yang dimiliki oleh individu, sehingga rasa sakit psikologis yang ada pada diri anggota kelompok dapat terjadi ketika anggota mengidentifikasi perasaan dan menceritakan pengalaman yang sulit, mungkin traumatis dari masa lalu. Karena itu, para pemimpin tidak hanya memiliki pengetahuan dan keterampilan, tetapi juga harus siap menghadapi emosi yang kuat yang mungkin timbul dalam kelompok (Jacob, dkk., 2012). Kepner (Corey, 2016) menggambarkan berbagai peran pemimpin dalam kelompok proses Gestalt menggunakan model tiga tahap, yaitu:

\section{Tahap pertama}

Pada tahap pertama (tahap awal) suatu kelompok, penekanan utama adalah identitas dan ketergantungan. Setiap anggota kelompok akan dipengaruhi oleh cara dia dianggap dan ditanggapi oleh anggota lain dan pemimpin yang ada dalam kelompok. Pemimpin membantu anggota mengeksplorasi pertanyaan yang dimiliki tentang identitas atau keberadaan mereka dalam kelompok. Pemimpin seharusnya mampu menciptakan iklim kepercayaan yang akan mendukung pengambilan risiko dan membuat koneksi antar anggota dalam kelompok. Begitu anggota menemukan kesamaan yang mereka miliki satu sama lain, kelompok siap untuk melaksanakan kegiatan.

\section{Tahap Kedua}

Pada tahap kedua penekanan utama adalah pengaruh dan ketergantungan. Selama masa transisi ini, anggota kelompok dapat berhadapan dengan masalah pengaruh, otoritas, dan kontrol dari luar dirinya. Tugas pemimpin adalah bekerja menuju peningkatan diferensiasi, perbedaan, dan fleksibilitas peran di antara anggota, serta mendorong anggota untuk menerima perbedaan norma yang dianut, dan secara terbuka mampu mengekspresikan perbedaan dan ketidakpuasan, serta membedakan peran dari orang.

\section{Tahap Ketiga}

Pada tahap ketiga (tahap kerja) keeratan hubungan dan ketergantungan dalam kelompok adalah tema utama. Pada tahap pengembangan grup ini, kontak nyata terjadi di dalam dan di antara anggota grup. Pada tahap ini para anggota telah bekerja melalui masalah pengaruh, kekuasaan, dan otoritas, sehingga mereka siap untuk tingkat pekerjaan yang lebih dalam, baik secara individu maupun dengan kelompok secara keseluruhan.

\section{Penilaian dalam Konseling Kelompok}

Penilaian pada dasarnya dua arah dan berkelanjutan, dimana penilaian dilakukan pada penyaringan prapenilaian, pada awal konseling, sepanjang konseling, pada akhir dan dalam mengevaluasi pekerjaan (Milner \& O’Byrne, 2004). Dua arah ini maksudnya terjadi pada sisi konselor dan pada sisi klien. Pada sisi klien akan muncul pemikiran apakah yang saya lakukan ini benar? Atau apakah kegiatan ini membantu menyelesaikan permasalahan saya atau sebaliknya? dan berbagai pertanyaan yang muncul mulai dari awal sesi konseling.

Pada bagian konselor, prosesnya melibatkan pengumpulan data, analisis, dan pengembangan formulasi yang didasarkan pada landasan teoritis untuk menghasilkan pernyataan tentang sifat, kemungkinan penyebab, beratnya masalah, kemampuan dalam menanganinya, pendekatan penanganan yang cocok dan terbaik, dan bagaimana cara penanganannya. Penilaian mencoba melibatkan aspek-aspek pendekatan untuk melihat bagaimana klien merespons atau untuk melihat apakah mereka memiliki kemampuan untuk menggunakan pendekatan. Akhirnya menemukan seperangkat informasi yang akan berguna bagi konselor dan klien dalam merencanakan kegiatan yang akan mereka lakukan. Menurut Jones (2011) dalam konseling yang sedang berjalan, asesmen dapat dilakukan sebagai bagian dari proses terapi dan bukan hanya sebagai prosedur diagnosis di awal, walaupun sebagian konselor melakukan asesmen awal. Klien perlu menyatakan kesediaannya terlibat dan merasa bahwa konselor adalah seseorang yang dapat dipercaya.

Secara umum, tujuan membuat penilaian bervariasi sesuai dengan kebutuhan dan kegunaan, Bayne et al. (Milner \& O’Byrne, 2004) berpendapat bahwa apapun orientasi konselor, ada enam tujuan utama penilaian dalam konseling, yaitu: (1) Membantu konselor memahami sifat dari masalah yang diajukan klien dan masalah 
terkait, (2) Mengidentifikasi faktor-faktor yang mungkin terkait dengan masalah dan pengalaman atau perilaku klien, (3) Menentukan harapan klien dan hasil yang diinginkan, (4) Mengumpulkan informasi dasar yang dapat dibandingkan dengan data berikutnya untuk mengevaluasi kemajuan, (5) Memfasilitasi pembelajaran dan motivasi klien dengan berbagi pandangan konselor tentang masalah yang dibahas, (6) Menghasilkan penilaian awal (formulasi) yang memberikan konselor dasar untuk membuat keputusan.

Konselor dapat menggunakan instrumen yang diselesaikan oleh klien, seperti skala masalah, log mini, daftar isian dan alat psikologis lainnya untuk membuat penilaian dan mungkin mengukur seberapa serius masalah tersebut. Tingkat kerincian dipengaruhi oleh teori konselor tentang sifat orang dan masalah mereka serta cara terbaik untuk membantu mereka. Beberapa, misalnya mereka yang memikirkan sistem keluarga, akan memperoleh silsilah keluarga atau garis kehidupan. Kuesioner memungkinkan pengumpulan banyak informasi tetapi membutuhkan wawancara untuk mengetahui apakah diperlukan penghubung dengan profesional lain atau siapa orang terbaik untuk membantu klien tertentu. Hill and Lambert (Whiston, 2009) menyatakan bahwa strategi terbaik dalam menilai melibatkan: (1) dengan jelas menentukan apa yang diukur; (2) mengukur perubahan dari berbagai perspektif (klien, konselor, dan pengamat luar); (3) menggunakan beragam jenis penilaian (mis., Skala penilaian, daftar periksa); (4) menggunakan tindakan berdasarkan gejala dan teori; dan (5) meneliti, sebanyak mungkin, pola perubahan seiring waktu.

\section{Aspek Penilaian Proses pada Konseling Kelompok Gestalt}

Selama tahap konseling kelompok, tugas pemimpin adalah membantu anggota belajar bagaimana mulai mengerjakan masalah yang membawa mereka ke kelompok. Adalah tugas anggota untuk memonitor pikiran, perasaan, reaksi, dan tindakan mereka dan untuk belajar mengekspresikannya secara lisan. Para pemimpin dapat membantu anggota mengenali dan menerima ketakutan dan pertahanan mereka, namun pada saat yang bersamaan, pemimpin kelompok berusaha menantang anggota untuk mengatasi kecemasan mereka dan keengganan dari berbagai hal yang mungkin dialami (Corey, dkk., 2013). Anggota idealnya memutuskan akan mengambil risiko apapun dan bersedia membicarakan tentang hal-hal yang mungkin mereka simpan selama ini, termasuk apa yang orang lain pikirkan tentang mereka. Pemimpin kelompok perlu memahami dan menghormati pengalaman anggota yang ketakutan atau enggan, dan mendorong mereka untuk mengeksplorasi keengganan dan ketakutan yang mungkin mereka miliki sewaktu berpartisipasi dalam kelompok.

Tahap kerja ditandai oleh produktivitas kelompok, yang diciptakan pemimpin dalam bentuk kerja efektif yang dilakukan pada tahap awal dan transisi. Kualitas dan eksplorasi diri meningkat, dan kelompok akan fokus membuat perubahan perilaku. Selama tahap kerja, kelompok dapat kembali ke tema sebelumnya yaitu kepercayaan, konflik, dan keengganan untuk berpartisipasi. Ketika kelompok itu menghadapi tantangan baru, tingkat kepercayaan yang lebih dalam dapat dicapai. Konflik baru dapat muncul dan komitmen diperlukan untuk melakukan pekerjaan yang sulit untuk maju. Semua anggota mungkin tidak dapat berfungsi pada tingkat intensitas yang sama, dan beberapa mungkin tetap sebagai pendengar dan pengamat, menahan diri dan lebih takut mengambil risiko.

Selama tahap kerja (kegiatan) kelompok, pemimpin harus memutuskan berapa aspek penilaian yang dilakukankan dengan berdasarkan tujuan kelompok, kepribadian dan kebutuhan anggota, dan tingkat kepercayaan, minat, dan komitmen. Jacobs, dkk. (2012) menawarkan tiga aspek yang perlu diperhatikan dalam penilaian proses pada konseling kelompok, yaitu:

Menilai manfaat, dimana pemimpin dapat meminta anggota kelompok menilai apa yang telah diperoleh selama sesi tersebut. Pemimpin dapat meminta anggota mengulas setiap topik yang dibahas, mengajak anggota untuk berkomentar tentang apa yang menonjol bagi mereka sehingga dapat membantu pemimpin mengevaluasi keefektifan pengalaman kelompok. Jika para anggota gagal mengingat poin-poin utama atau jika mereka tidak banyak bicara, ada kemungkinan kelompok tersebut tidak menguntungkan seperti yang diharapkan.

Menilai minat dan komitmen anggota, pemimpin dapat mengamati energi sepanjang sesi, dimana pemimpin mencari pola ketidaktertarikan yang mungkin disebabkan karena tekanan dan kekhawatiran dari luar. Ketika minat anggota tampaknya menurun, pemimpin pertama-tama dapat menilai apakah hilangnya minat berlaku untuk semua orang atau hanya beberapa anggota. Ketika hanya beberapa anggota yang kehilangan minat, pemimpin dapat mencoba memahami alasannya. Mungkin tingkat minat anggota rendah sejak awal karena mereka dipaksa berada di grup. Anggota juga mungkin tidak berkomitmen pada grup karena mereka merasa kontennya tidak menarik, merasa kebutuhan mereka tidak terpenuhi, dan tidak siap untuk melakukan perubahan dalam hidup mereka. Apa pun alasannya, pemimpin akan berusaha untuk memperbaiki situasi. Pemimpin dapat mengubah format grup untuk menghasilkan minat dan komitmen baru, atau membawa masalah untuk diskusi dalam kelompok dengan mengingat bahwa akan ada perbedaan pendapat. Diskusi dapat 
membantu dalam mengklarifikasi tujuan kelompok dan dalam mengungkap alasan anggota tertentu tidak tertarik.

Menilai partisipasi setiap anggota, pemimpin dapat mempertimbangkan frekuensi dan gaya partisipasi masing-masing anggota. Meskipun tidak ada cara yang "benar" untuk berpartisipasi dalam kelompok, partisipasi aktif dan verbal biasanya lebih baik bagi sebagian besar anggota daripada hanya mengamati atau sesekali berkomentar. Konselor mengupayakan untuk mencoba membuat anggota yang pendiam membagikan pikiran dan perasaan mereka, dengan harapan bahwa mereka akan menjadi lebih nyaman berbagi dalam kelompok.

Selanjutnya Menurut Milner \& O’Byrne (2004) penilaian memiliki setidaknya tiga aspek: Pertama, menggambarkan masalah; Kedua, menemukan kekuatan pribadi dan sistemik serta kemampuan unik yang akan membantu menciptakan perubahan; dan Ketiga, memutuskan dengan klien di mana harus memfokuskan intervensi, apakah pada keterampilan, proses kognitif, perasaan, perilaku, pemecahan masalah atau pengembangan solusi. Para terapis gestalt lebih banyak memanfaatkan interaksi dalam kelompok dan kontribusi dari para anggota kelompok dengan meminta anggota untuk berbicara satu sama lain dengan menekankan pada komunikasi di sini dan sekarang (here and now). Yontef dan Jacobs (dalam Jones, 2012) menekankan satusatunya tujuan terapi gestalt adalah kesadaran, baik kesadaran dalam bidang tertentu, kesadaran tentang konten, dan juga tentang proses atau kebiasaan yang menghambat kesadaran, serta kesadaran tentang proses.

Ketika klien menjadi lebih sadar akan masalah mereka dan mulai membuat perubahan tambahan, proses penilaian menjadi lebih kaya dan semakin menggunakan berbagai metode penilaian untuk mengkomunikasikan data untuk memfasilitasi perencanaan dan intervensi pengobatan (Hays, 2013). Penilaian tahap perubahan klien sangat penting.

\section{KESIMPULAN}

Secara keseluruhan, penilaian sangatlah penting karena dapat membantu konselor menentukan permasalahan klien dan mempelajari orientasi klien dalam memecahkan permasalahan, sehingga konselor, klien dan anggota bekerja bersama-sama dalam kelompok untuk mencari solusi yang membawa perubahan positif baik pada klien yang bersangkutan ataupun anggota kelompok yang terlibat di dalamnya. Penilaian selama konseling berkaitan dengan kemajuan dan hasil. Pertanyaan yang sering diajukan pada tahap ini meliputi: "apakah sesuai dengan jalur yang benar? apakah masalahnya berkurang? apakah perlu mengubah pendekatan? apakah ada cukup perubahan yang terjadi pada klien?. Kemajuan juga dapat dinilai dengan menggunakan pertanyaan berskala seperti skala untuk perasaan, pikiran, perilaku, sensasi, hubungan, dan tujuan tertentu. Khusus untuk pendekatan konseling kelompok gestalt ditekankan pada tercapainya kesadaran klien sehingga bisnis yang belum selesai (unfinished business) dapat terentaskan dengan baik dan anggota kelompok dapat memahami apa dan bagaimana mereka berpikir, merasakan, dan melakukan ketika mereka berinteraksi dengan orang lain dalam kelompok. Anggota didorong dan dibimbing dalam percobaan dengan perilaku baru sebagai cara untuk meningkatkan pemahaman diri.

\section{DAFTAR RUJUKAN}

Berg, R. C., Landreth, G. L., Fall, K. A. (2006). Group Counseling Concepts and Procedures (4th ed.). New York: Routledge.

Corey, M. S., Corey, G., Corey, C., (2013). Group Process and Practice, (9th ed.). Pacific Grove, CA: Brooks/Cole.

Corey, G. (2016). Theory and Practice of Group Counseling, (9th ed.). Pacific Grove, CA: Brooks/Cole.

Gladding, S. T., (2012). Konseling Profesi yang Menyeluruh. Alih Bahasa Winarno \& Lilian Yuwono. Jakarta: Indeks

Hays, D. G. (2013). Assessment in Counseling A Guide to the Use of Psychological Assessment Procedures. Unites States: American Counseling Association.

Jacobs, E., Masson, B., Harvi, R., \& Schimmel, C. (2012). Group Counseling: Strategies and Skills, (7th ed.). Pacific Grove, CA: Brooks/Cole.

Jones, R. N., (2011). Teori dan Praktik Konseling dan Terapi. Alih Bahasa Helly, P.S., \& Sri, M. S. Yogyakarta: Pustaka Pelajar.

Milner, J., O'Byrne, P., (2004). Assessment in Counselling. New York, Palgrave Macmillan.

Perls, F. S. (1981). The Gestalt Approach \& Eyewitness to Therapy. New York: Bantam Books.

Whiston, S. C., (2009). Principles and Applications of Assessment in Counseling. Belmont: Brooks Cole. 